\title{
STABILKAH PERMINTAAN UANG DI INDONESIA SEBELUM DAN SELAMA KRISIS?
}

\author{
Triatmo Doriyanto *)
}

Tulisan ini mencoba mengetahui apakah permintaan uang riil di Indonesia selama periode sebelum krisis (sebelum Agustus 1997) dan saat krisis tetap stabil. Analisis stasioner dan integrasi dengan menggunakan uji Augmented Dickey Fuller serta analisis kointegrasi dengan menggunakan uji Johansen menunjukkan adanya hubungan kointegrasidi antara variabel-variabel: currency riil dan PDB riil. Model permintaan uang riil dinamis dengan menggunakan Error Correction Model (ECM) menunjukkan konsistensi parameter secara signifikan, juga pada saat krisis.

\footnotetext{
*)Triatmo Doriyanto: Peneliti Ekonomi Junior, Bagian Studi Ekonomi Makro, DKM, Bank Indonesia, email : triatmo@bi.go.id

Penulis mengucapkan terima kasih kepada Bpk. Halim Alamsyah, Bpk. Charles PR Joseph, Bpk. Iskandar, Yati Kurniati, Doddy Zulverdi, M. Firdaus Muttaqin, Firman Mochtar, Solikin dan Reza Anglingkusumo, atas diskusidiskusi yang telah dilakukan dan bantuan penelitian yang diberikan.
} 


\section{Pendahuluan}

$\mathrm{K}$

risis moneter yang melanda Indonesia sejak pertengahan tahun 1997 dan dipicu oleh melemahnya nilai tukar rupiah terhadap USD telah mengarahkan kepada diadopsinya sistem nilai tukar mengambang (free floating exchange rate). Hal ini memberi dampak yang besar kepada kebijakan moneter yang diambil oleh BI mengingat nilai tukar tidak lagi bertindak sebagai jangkar perekonomian. Dengan demikian, program moneter yang dicanangkan adalah mempertahankan stabilitas harga melalui pengaturan jumlah uang beredar (dalam hal ini currency).

Tulisan-tulisan tentang stabilitas permintaan uang riil di Indonesia pernah dibuat oleh Desk Penelitian dan Pengembangan, URES (1995) dan Solikin (working paper), di Jurusan Ekonomi, Universitas Michigan (1998). Dalam tulisan pertama, digunakan ECM sebagai dasar untuk menguji stabilitas uang beredar (M1 dan M2) dengan menggunakan 2 prosedur penaksiran. Prosedur pertama adalah menggunakan penaksiran 2 tahap, yaitu menaksir keseimbangan dalam jangka panjang fungsi permintaan uang riil dan menghitung residualnya; sedangkan tahap berikutnya menaksir dalam jangka pendek dengan cara memasukkan residual jangka panjangnya (lag 1 periode). Prosedur kedua adalah dengan mensubstitusi faktor residual sekaligus dalam 1 persamaan dan menaksir parameterparameter jangka panjang serta jangka pend ek secara bersama-sama. Pada tulisan Solikin, hanya digunakan prosedur pertama.

Dalamtulisan ini, hanya akan digunakan prosedur pertama dan akan dibahas apakah permintaan uang riil tetap stabil sebelum dan sel ama krisis di Indonesia. Jika permintaan uang tersebut stabil, maka real balance dalam jangka panjang akan berhubungan secara proporsional dengan PDB Riil. Artinya, variabel-variabel tersebut berkointegrasi. Dengan menggunakan uji stasioner dan integrasi dengan Augmented Dickey Fuller serta analisis kointegrasi dengan menggunakan uji Johansen, tulisan ini meneliti permintaan uang dalam jangka panjang dari tahun 1988:01 - 1999:03 berdasarkan data bulanan. Dinamika permintaan uang riil ditaksir dengan ECM dan stabilitasnya diuji. Periodestudi ini terdiri dari masa sebelum krisis (sesudah Pakto $1988 \mathrm{~s}$ / d sebelum pemberlakuan sistem floating exchange rate) dan selama krisis (sejak 1997:08s/ d 1999:03).

Hasil akhir dari studi ini menunjukkan bahwa demand currency riil tetap stabil selama krisis di Indonesia. Tulisan ini menemukan bukti kuat terjadinya stabilitas permintaan uang riil dalam jangka panjang yang diindikasikan oleh adanya kointegrasi currency riil dan PDB riil. Uji stabilitas terhadap parameter-parameter model dinamik (jangka pendek) menunjukkan konsistensi dalam seluruh periode. Spesifikasi model dinamik memasukkan lag : currency, error correction, nilai tukar, tingkat suku bunga deposito 1 bulan, dan inflasi. Efek perubahan PDB riil nampaknya tidak signifikan terhadap permintaan uang riil dalam jangka pendek. 
Organisasi penulisan adalah sbb. : bagian II menjelaskan data yang dipergunakan dalam analisis. Bagian III menggambarkan hasil uji kointegrasi. Bagian IV menjelaskan proses penaksiran ECM. Uji stabilitas permintaan uang riil sebelum dan selama krisis dijelaskan di dalam bagian V. Bagian VI adalah kesimpulan.

\section{D ata yang Dipergunakan}

Studi ini mempergunakan observasi bulanan (seasonally unadjusted) ${ }^{1}$ selama periode 1988:01 - 1999:03 untuk currency (CURRENCY) yang dideflasikan terhadap Indeks Harga Konsumen (IHK) dengan tahun dasar 1996. Produk Domestik Bruto Riil (PDBREAL) ${ }^{2}$ dipergunakan sebagai variabel untuk menaksir transaksi permintaan uang yang terjadi. Data kwartalan yang akan dipergunakan telah dilakukan "spline"3 untuk menjadi data bulanan. Tingkat inflasi (INFBUL) dan suku bunga yang dipergunakan adalah suku bunga deposito 1 bulan (DEP1) sebagai penaksir opportunity cost menyimpan currency. Nilai tukar (ER) juga berpengaruh terhadap permintaan uang terutama setelah pemberlakuan sistem nilai tukar berubah menjadi freefloating ${ }^{4}$.

Gambar 1 menunjukkan hubungan log(CURRENCY/ IHK), log(PDBREAL) dan ER serta hubungan DEP1 dengan INFBUL untuk periode 1988:01 - 1999:03. Keempat series menggambarkan peristiwa-peristiwa makroekonomi penting yang terjadi dalam periodeini.

Log(CURRENCY/ IHK) meningkat terus sejak awal periode sejak diberlakukannya Pakto 1988yang memberikan dorongan lebih besar kepada masyarakat untuk berhubungan dengan perbankan sekaligus meningkatkan permintaan uang. Pada tahun 1991 terjadi peningkatan tingkat suku bunga deposito karena adanya kebijakan uang ketat. Puncaknya adal ah pada saat terjadinya krisis yang dimulai pada bulan Juli 1997 sampai dengan awal tahun 1998. Nampak bahwa Iog(PDBREAL) dan ER mencerminkan perilaku log(CURRENCY/ IHK). Inflasi bulanan (INFBUL) dan tingkat suku bunga deposito 1 bulan (DEP1), setelah dimulainya krisis, bergerak bersama-sama, namun pergerakan inflasi lebih bervariasi. Hal ini mencerminkan krisis keuangan yang sedang terjadi, berbeda dengan situasi sebelum krisis dimana pergerakan inflasi hampir konstan. Grafik tersebut

\footnotetext{
1 Data $\log$ (CURRENCY/IHK) dan log (PDBREAL) yang telah dilakukan seasonal adjustment telah diuj, namun error correctionnya tidak stasioner jika dilakukan uji unit root dengan ADF (lihat lampiran).

2 Berbeda dengan IMF Working Paper, Can Currency Demand be Stable Under a Financial Crisis ? The Case of Mexico, April 1999 yang mempergunakan data konsumsi sektor swasta sebagai pengganti PDBR. Data konsumsi kwartalan yang telah di"spline" juga telah diuji, namun hasilnya tidak signifikan.

3 Prinsip metode " spline" adalah melakukan interpolasi data kwartalan menjadi data bulanan. Berbeda dengan paper IMF di atas, untuk menjadi data bulanan, data kwartalan diulang dalam kwartal yang sama.

4 Uji restriksi 0 pada koofisien ER menunjukkan penolakan yang sangat kuat (nilai Likelihood Ratio dan F statistik yang sangat besar).
} 
mencerminkan hubungan positif antara permintaan uang riil dengan output dan nilai tukar serta hubungan negatif antara permintaan uang dengan inflasi dan tingkat suku bunga deposito 1 bulan. Hal ini mendukung fakta bahwa dalam jangka panjang terjadi kointegrasi di antara variabel-variabel tersebut di atas.

G ambar 1.

G rafik hubungan antara log(CURREN CY/IHK ), $\log (P D B R E A L)$ dan ER serta hubungan DEP1 dengan IN FBUL untuk periode 1988:01 - 1999:03
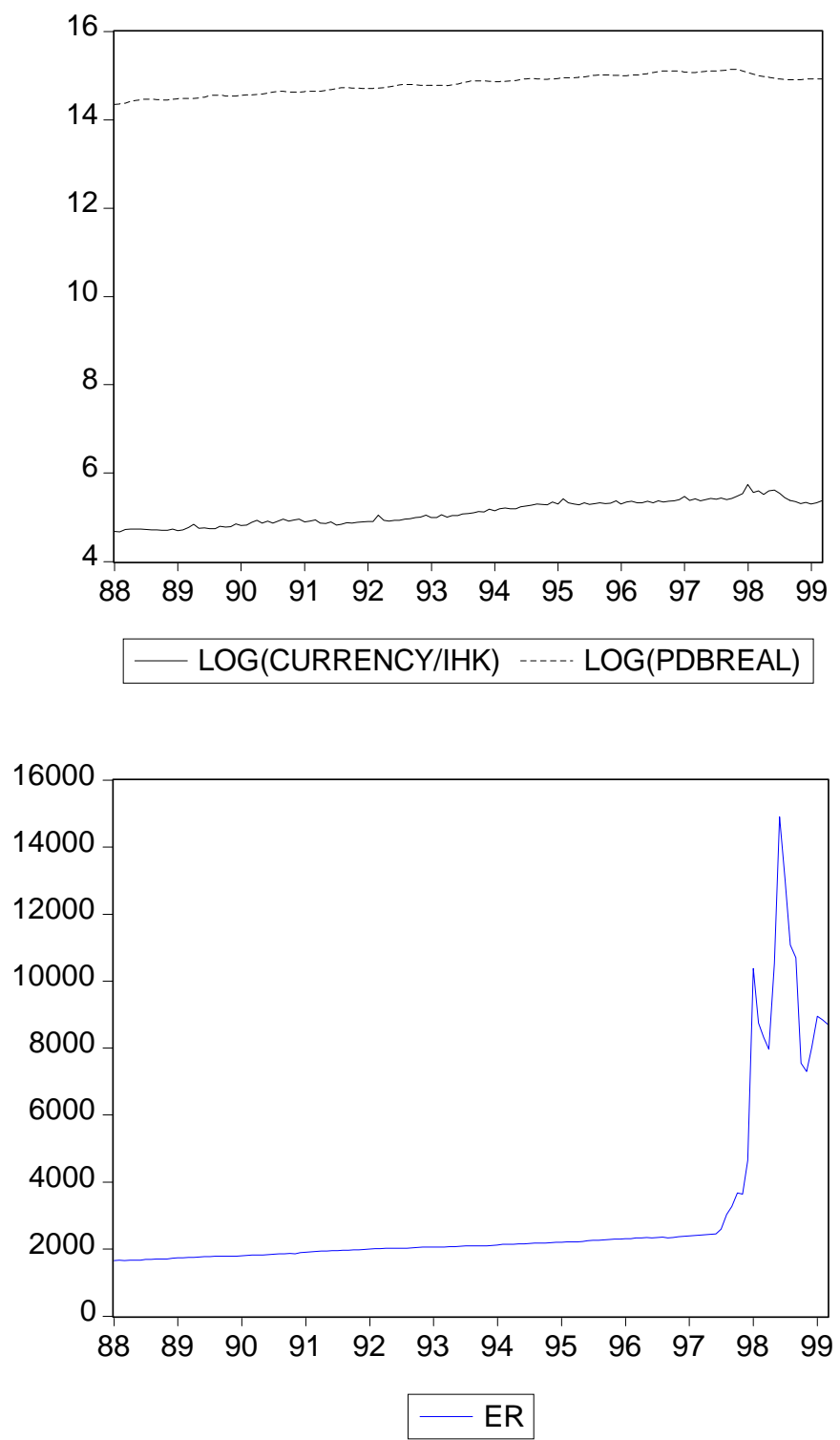


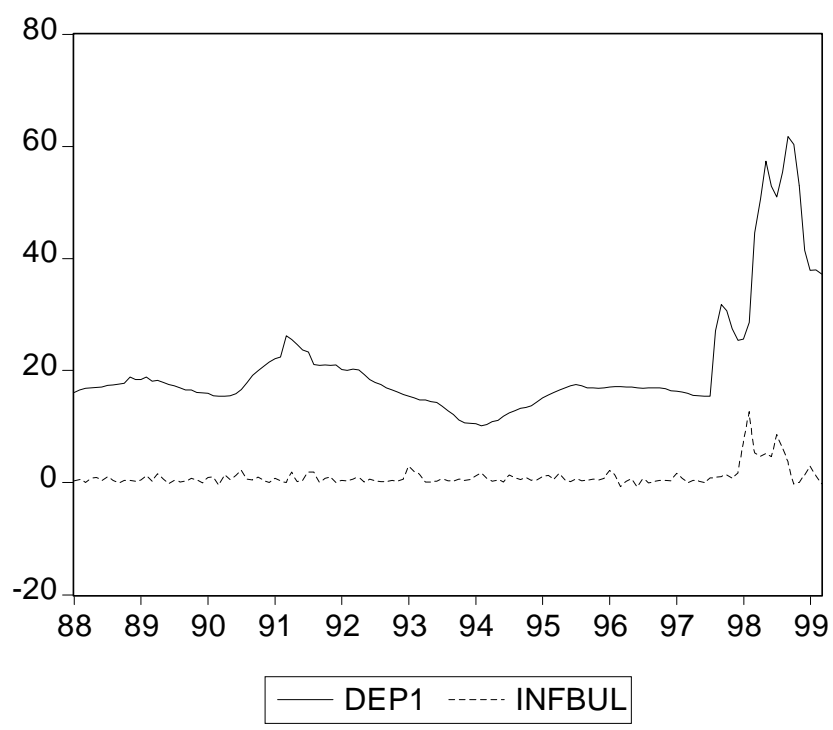

Transformasi logaritma dilakukan terhadap variabel-variabel dalam persamaan permintaan uang jangka panjang :

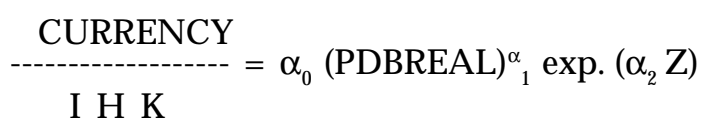

dimana Z adalah faktor-faktor lain yang mempengaruhi permintaan uang.

TestA ugmented Dickey-Fuller (ADF) digunakan untuk menguji stasioner tidaknya suatu variabel dan orde integrasi setiap variabel yang digunakan. Hasilnya dilaporkan dalam Tabel 1. Seluruh variabel (kecuali inflasi - INFBUL) terintegrasi dengan orde1-I(1). Namun, untuk kemudahan ${ }^{5}$, orde inflasi disamakan dengan ordesuku bunga - DEP1.

5 Menurut Pagan dan Wickens (1989), dimungkinkan untuk menggabungkan variabel-variabel yang berbeda orde integrasinya, jika dalam 1 persamaan terdapat lebih dari 2 variabel. 
Tabel 1.

Test A ugmented D ickey-Fuller (A DF) untuk menentukan orde integrasi setiap variabel.

\begin{tabular}{|c|c|c|c|c|}
\hline Variabel & ADF Statistik & Jumlah Lag & $\begin{array}{l}\text { Konstan } \\
\text { termasuk }\end{array}$ & $\begin{array}{l}\text { Trend } \\
\text { termasuk }\end{array}$ \\
\hline $\log (\mathrm{CURRENCY} / \mathrm{IHK})$ & $-2,229$ & 3 & $\mathrm{Ya}$ & Ya \\
\hline $\log (\mathrm{PDBREAL})$ & $-2,812$ & 2 & Ya & Ya \\
\hline ER & $-2,422$ & 8 & Ya & Ya \\
\hline DEP1 & $-2,549$ & 7 & Ya & Ya \\
\hline INFBUL : 1988:011999:03 & $-4,839 *$ & 0 & $\mathrm{Ya}$ & - \\
\hline : 1997:07-1999:03 & $-2,106$ & 0 & Ya & - \\
\hline $\mathrm{d}(\log (C U R R E N C Y /$ IHK $))$ & $-4,510^{*}$ & 1 & $\mathrm{Ya}$ & - \\
\hline $\mathrm{d}(\log ($ PDBREAL $))$ & $-5,87^{*}$ & 0 & - & - \\
\hline$d(E R)$ & $-9,368 *$ & 1 & - & - \\
\hline$d(D E P 1)$ & $-7,423^{*}$ & 1 & - & - \\
\hline d(INFBUL) & $-15,328 *$ & 1 & - & - \\
\hline
\end{tabular}

Catt. : - Periode test untuk seluruh variabel adalah 1988:01 - 1999:03, kecuali dinyatakan lain.

- * menyatakan penolakan terhadap hipotesis nol : adanya unit root pada level $5 \%$.

- Uji untuk INFBUL inkonklusif, uji dengan menggunakan periode yang berbeda tidak dapat menolak hipotesis nol : unit root $\left(\mathrm{H}_{\mathrm{o}}\right.$ : variabel bukan stasioner).

\section{Perilaku Jangka Panjang dan Kointegrasi}

Pada bagian ini, akan diteliti adanya kointegrasi di antara log(CURRENCY/IHK) dan log(PDBREAL), DEP1, ER dan INFBUL menggunakan uji Johansen (1988). Untuk terjadinya kointegrasi, seluruh variabel-variabel tersebut harus diitegrasikan dengan orde yang sama. Hal ini telah dilakukan dengan uji ADF tersebut di atas ${ }^{6}$.

Tabel 2 menunjukkan hasil penaksiran kointegrasi dan pengecekannya dengan uji ADF bahwa variabel-variabel tersebut berkointegrasi dengan orde 1. Ditunjukkan Eigenvalues dan statistik Likelihood Ratio. Statistik LR menunjukkan keberadaan 1 vektor kointegrasi padalevel $5 \%$. Sehingga, berdasarkan pada statistik di atas, dan asumsi bahwa

6 Uji dengan ADF terhadap residual persamaan jangka panjang (ECTR1) menunjukkan penolakan hipotesis nol adanya unit root pada level $5 \%$. Hal ini membuktikan bahwa variabel-variabel yang dimasukkan ke dalam persamaan jangka panjang berkointegrasi dengan orde 1 (lihat Enders, 1995). 
penaksiran tidak mengabaikan adanya potensi vektor kointegrasi, maka prosedur dilakukan dengan menggunakan 1 vektor kointegrasi.

Tabel 2.

Hasil penaksiran kointegrasi.

\begin{tabular}{|c|c|c|c|c|}
\hline \multicolumn{5}{|c|}{$\begin{array}{l}\text { Sample: 1988:01 1999:03 } \\
\text { Included observations: } 130 \\
\text { Series: LOG(CURRENCY/ IHK) LOG(PDBREAL) }\end{array}$} \\
\hline Eigenvalue & $\begin{array}{l}\text { Likelihood } \\
\text { Ratio }\end{array}$ & $\begin{array}{l}5 \text { Percent } \\
\text { Critical Value }\end{array}$ & $\begin{array}{l}1 \text { Percent } \\
\text { Critical Value }\end{array}$ & $\begin{array}{l}\text { Hypothesized } \\
\text { No. of CE(s) }\end{array}$ \\
\hline 0.148307 & 24.22303 & 15.41 & 20.04 & None** \\
\hline 0.025471 & 3.354171 & 3.76 & 6.65 & Atmost 1 \\
\hline \multicolumn{5}{|c|}{$\begin{array}{l}*(* *) \text { denotes rejection of the hypothesis at } 5 \%(1 \%) \text { significancelevel } \\
\text { L.R. test indicates } 1 \text { cointegrating equation(s) at } 5 \% \text { significancelevel }\end{array}$} \\
\hline \multicolumn{5}{|c|}{ N ormalized Cointegrating Coefficients: 1 Cointegrating Equation(s) } \\
\hline \multicolumn{2}{|c|}{ LOG(CURRENCY/IHK) } & LOG(PDBREAL) & $\mathrm{C}$ & \\
\hline \multirow[t]{2}{*}{1} & & -1.164076 & 12.12411 & \\
\hline & & -0.07035 & & \\
\hline \multicolumn{2}{|c|}{ Loglikelihood } & 776.7489 & & \\
\hline
\end{tabular}

Hasil penaksiran vektor kointegrasi menggambarkan rumusan permintaan uang jangka panjang, arahnya benar (1,164 untuk PDBREAL) ${ }^{7}$. Jadi, perkiraan elastisitas PDBREAL terhadap permintaan uang adalah mendekati nilai 1 . Nilai ini mendekati elastisitas PDBREAL terhadap M 1 dalam tulisan Solikin. ${ }^{8}$ Tingkat suku bunga, inflasi dan nilai tukar tidak berpengaruh terhadap pada permintaan uang dalam jangka panjang. Hal ini menunjukkan bahwa dalam periodestudi, permintaan uang dalamjangka panjang tetap stabil.

7 Variabel DEP1 dan ER juga diuji, namun tidak signifikan.

8 Hasil penaksiran Solikin untuk permintaan uang riil (M1riil) dalam jangka panjang $\quad: \log ($ M1riil $)=1,664+1,109$ $\log$ (GDPriil) - 0,025 Rdeposito 3 bulan. Sedangkan hasil penaksiran Desk Penelitian dan Pengembangan - URES untuk permintaan uang riil (M1riil) : $\log ($ M1riil $)=-2,25+1,41 \log ($ GDPriil $)$. 
Persamaan jangka panjangnya adalah sbb. :

$\log ($ CURRENCY/ IHK) $=-12,12411+1,164076 \log ($ PDBREAL $)$

\section{Error Correction Model}

Penaksiran persamaan kointegrasi mengungkapkan faktor-faktor yang mempengaruhi permintaan uang dalam jangka panjang. Dalam jangka pendek, deviasi yang terjadi akibat hubungan ini menggambarkan shock terhadap variabel-variabel yang ada. Dinamika yang menggambarkan perilaku dalam jangka pendek sangat berbeda dengan yang terjadi dalam jangka panjang. Engle dan Granger (1987) menegaskan bahwa jika terdapat kointegrasi di antara variabel-variabel yang tidak stasioner, pasti akan terdapat hubungan error correction dalam data. Dalam bagian ini, akan dibahas penaksiran error correction, dengan memasukkan deviasi yang terjadi dalam jangka panjang dan dinamika jangka pendek. Di dalam model ini, dinamika jangka pendek dibuat dengan memasukkan perbedaan pertama (first difference). Penyesuaian terhadap deviasi permintaan uang riil jangka panjang dilakukan dengan cara memasukkan error correction yang ditaksir dalam bagian sebel umnya. Stabilitas prediksi error correction model akan dibahas dal am bagian berikutnya.

Model error correction ditaksir untuk periode 1988:01 - 1999:03. Model ini pada awalnya ditaksir dengan memasukkan 6 lag untuk seluruh variabel $\Delta(\log (C U R R E N C Y /$ IHK $))$, $\Delta($ INFBUL $), \Delta($ ER),$\Delta$ (DEP1), dan error correction sebagai tambahan. Struktur lag akhir ditentukan berdasarkan signifikansi setiap lag dan kombinasi lag setiap variabel. Model akhir adalah :

$$
\begin{aligned}
& \Delta(\log (\text { CURRENCY } / \text { IHK }))=0,00493-0,369 \Delta(\log (\text { CURRENCY } / \text { IHK }))_{t-1}-0,002003 \\
& (1,899) \quad(-5,528) \\
& \Delta(\mathrm{DEP} 1)_{\mathrm{t}-1}-0,00452 \Delta(\mathrm{INFBUL})_{\mathrm{t}-1}+0,0000298 \\
& (-1,750) \\
& \Delta(E R)_{t}-0,152 E C T R 1_{t-1} \\
& (-4,323)
\end{aligned}
$$

dimanaECTR 1 adalah error correction. Tabel 3 menggambarkan hasil penaksiran tersebut. Semua kooefisien mempunyai tanda yang benar. Nilai F statistik menunjukkan bahwasemua koofisien signifikan pada level $1 \%$ (kecuali intersep dan variabel suku bunga serta inflasi pada level $10 \%$ ), dan persamaan tersebut telah sesuai dengan spesifikasi. Residualnya memiliki : homoskedastisitas (ARCH-LM), distribusi normal (NORM C²), dan tidak berkorelasi pada lag 11 . Gambar 2 menunjukan nilai aktual, nilai fitted dan residual penaksiran tersebut. 
Tabel 3.

H asil penaksiran ECM

\begin{tabular}{|lllll|}
\hline $\begin{array}{l}\text { Dependent Variable: D(LOG(CURRENCY/ IHK)) } \\
\text { Method: Least Squares }\end{array}$ & & & \\
Sample(adjusted): 1988:03 1999:03 & & & \\
Included observations: 133 after adjusting end points & & \\
\hline Variable & Coefficient & Std. Error & t-Statistic & Prob. \\
C & 0.00617 & 0.003248 & 1.899382 & 0.0598 \\
D(LOG(CURRENCY(-1)/ IHK(-1))) & -0.36923 & 0.066788 & -5.528389 & 0 \\
D(DEP1(-1)) & -0.002003 & 0.001404 & -1.426818 & 0.1561 \\
D(INFBUL(-1)) & -0.004518 & 0.002581 & -1.750337 & 0.0825 \\
D(ER) & $2.98 E-05$ & $4.15 E-06$ & 7.176137 & 0 \\
ECTRI(-1) & -0.151574 & 0.035061 & -4.323126 & 0 \\
\hline R-squared & 0.460789 & Mean dependent var & 0.005255 \\
Adjusted R-squared & 0.43956 & S.D. dependent var & 0.049578 \\
S.E. of regression & 0.037115 & Akaikeinfo criterion & -3.705515 \\
Sum squared resid & 0.174948 & Schwarz criterion & -3.575123 \\
Log likelihood & 252.4167 & F-statistic & 21.70588 \\
Durbin-Watson stat & 2.087306 & Prob(F-statistic) & 0 \\
\hline
\end{tabular}

\begin{tabular}{|lll|}
\hline & Statistics & Probability \\
\hline JB & 6.472510 & 0.039311 \\
ARCH(1) & 1.283865 & 0.259267 \\
BG - LM test & 1.154511 & 0.326511 \\
WhiteTest & 1.129633 & 0.345774 \\
\hline
\end{tabular}

Catt : - Jarque - Bera (JB) adalah uji untuk normalitas, tidak dapat ditolak pada level $1 \%$.

- ARCH adalah uji untuk tidak adanya autoregressive conditional heteroscedasticity, tidak dapat ditolak pada level $1 \%$.

- Breusch - Godfrey LM test adalah uji untuk tidak adanya serial correlation, tidak dapat ditolak pada level $1 \%$.

- White Test adalah uji untuk tidak adanya heteroskedastisitas, tidak dapat ditolak pada level $1 \%$.

Persamaan di atas dengan jelas dapat diinterpretasikan. Pelaku menentukan berapa besar currency yang dipegang dalam jangka panjang berdasarkan kebutuhan transaksi. Dalam jangka pendek, mereka menyesuaikan kebutuhannya sekitar $15 \%$ terhadap deviasi keseimbangan bulan lalu. Pelaku ekonomi bereaksi terhadap perubahan suku bunga, inflasi 
dan nilai tukar (meskipun pengaruhnya kecil). Dapat dicatat bahwa level transaksi nampaknya tidak berpengaruh terhadap permintaan uang dalam jangka pendek, ini dapat terjadi karena pendekatan bulanan PDBREAL yang menggunakan data kwartalan.

\section{G ambar 2.}

Nilai aktual, nilai fitted dan residual penaksiran ECM

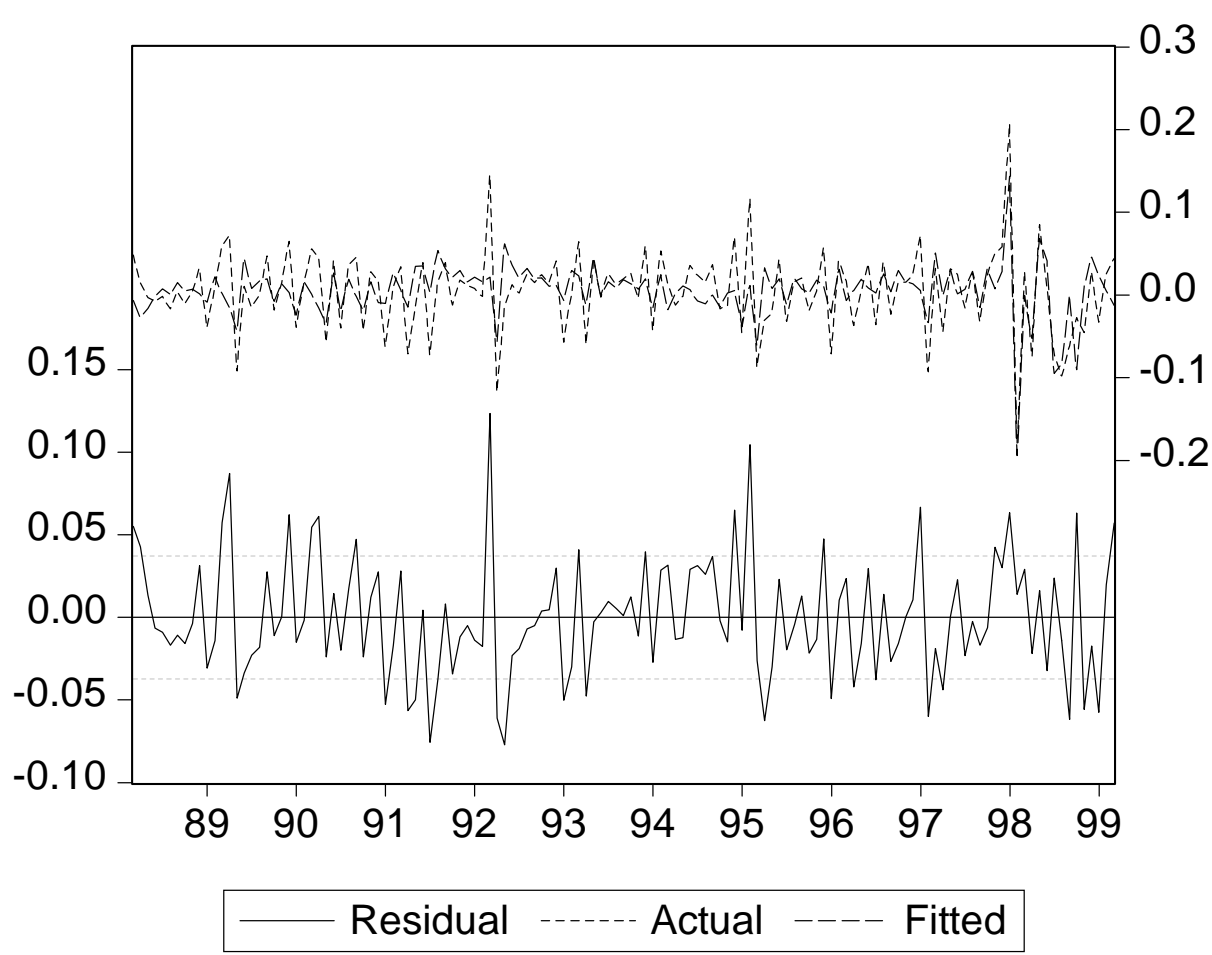

\section{Stabilitas Parameter dan Prediksi}

Untuk mengetahui bahwa persamaan yang dibuat sudah sesuai dengan spesifikasi, perlu dilakukan uji stabilitas pada parameternya. Prediksi dilakukan jika parameter yang diuji menunjukkan konsistensi dalam seluruh periode. Potensi ketidakstabilan parameter menurun selama krisis berlangsung dimana efek dari variabel-variabel yang ada dapat berubah dan variabel lainnya menjadi signifikan (contohnya adalah perubahan sistem nilai tukar dari managed floating menjadi free floating). Dalam bagian ini, akan dievaluasi konsistensi parameter sebelum dan selama krisis serta prediksi nilai nominal Currency untuk periode 1994:04 s/ d 2000:10. Dievaluasi stabilitas penaksiran selama periode studi menggunakan uji forecast Chow, break point Chow, Ramsey Reset dan CumulativeSum of Squares - Recursivetest. 
Gambar 3 menunjukkan uji C umulative Sum of Squares - Recursiveterhadap parameter $\triangle \log (C U R R E N C Y / I H K)$. CumulativeSum of Squares-recursiveuntuk $\triangle \log$ (CURRENCY/ IHK) tetap berada di dalam rentang level $5 \%$ pada seluruh periode studi. Uji : forecast Chow, break point Chow dan Ramsey Reset dicantumkan dalam tabel 4. Parameter penaksiran menunjukkan konsistensi. Seluruh jenis uji menunjukkan adanya konsistensi paramater yang ditaksir selama periodestudi.

\section{G ambar 3.}

Uji C umulativeSum of Squares - Recursiveterhadap : $\triangle \log ($ CURREN CY/IHK ) :

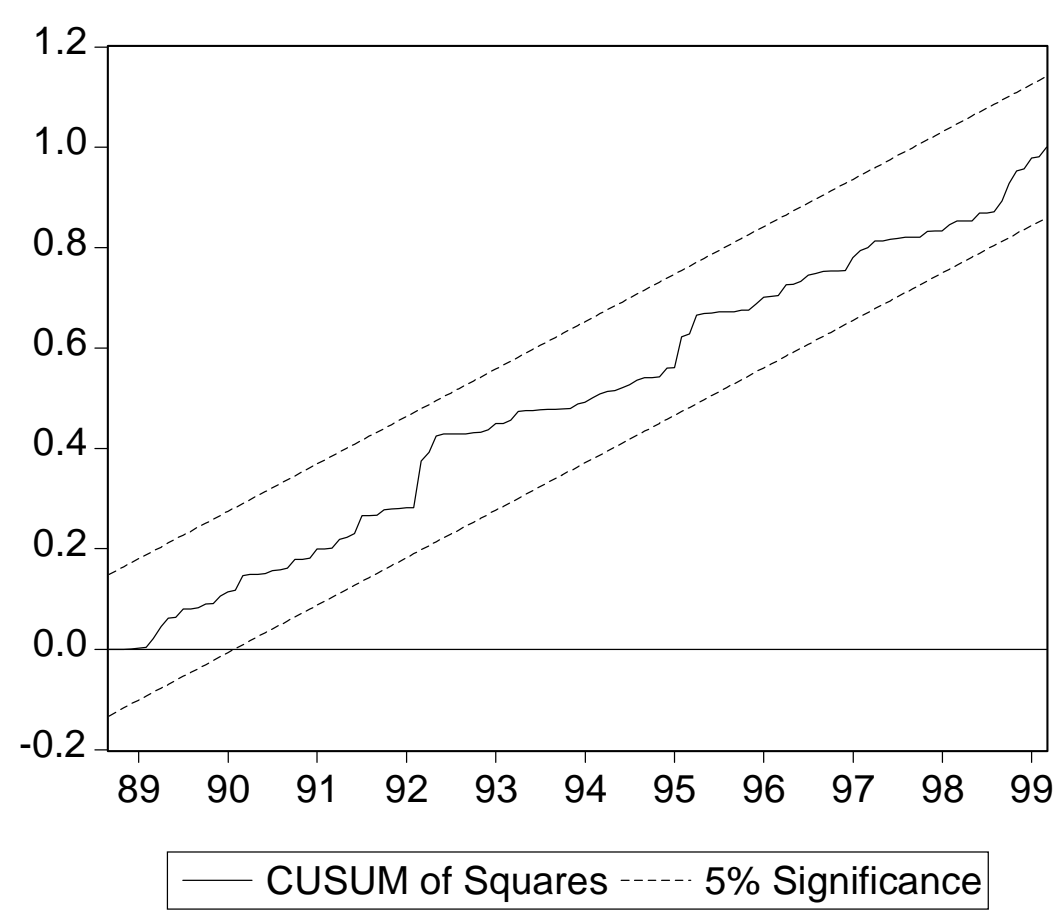

Untuk konfirmasi lebih jauh, dilakukan penghitungan forecast Chow, break point Chow dan Ramsey Reset selama periode 1997:08-1999:03. 
Tabel 4.

Uji Forecast Chow, Break Point Chow dan Ramsey Reset

\begin{tabular}{|c|c|c|c|}
\hline \multicolumn{4}{|c|}{ Chow Forecast Test: Forecast from 1997:08 to 1999:03 } \\
\hline F-statistic & 1.189916 & Probability & 0.2773 \\
\hline Loglikelihood ratio & 26.71009 & Probability & 0.143619 \\
\hline \multicolumn{4}{|c|}{ Chow Breakpoint Test: 1997:08 } \\
\hline F-statistic & 0.694002 & Probability & 0.654889 \\
\hline Loglikelihood ratio & 4.499976 & Probability & 0.609342 \\
\hline \multicolumn{4}{|l|}{ Ramsey RESET Test: } \\
\hline F-statistic & 0.907344 & Probability & 0.342644 \\
\hline Loglikelihood ratio & 0.95432 & Probability & 0.328622 \\
\hline
\end{tabular}

Pada gambar 4 ditunjukkan grafik currency aktual (CURRENCY), model (CURREN CYFMOD) dan prediksinya (CURREN CYFORC) dengan asumsi sampai dengan bulan Oktober 2000 : tingkat pertumbuhan riil 0\%, suku bunga 14\%, nilai tukar rupiah Rp. 6.500,- dan inflasi untuk tahun 1999 serta tahun 2000 masing-masing 7,3\% dan 6\% sesuai dengan prediksi MODBI.

G ambar 4.

Grafik CURRENCY,CURRENCYFM ODEL dan CURRENCYFORCAST.

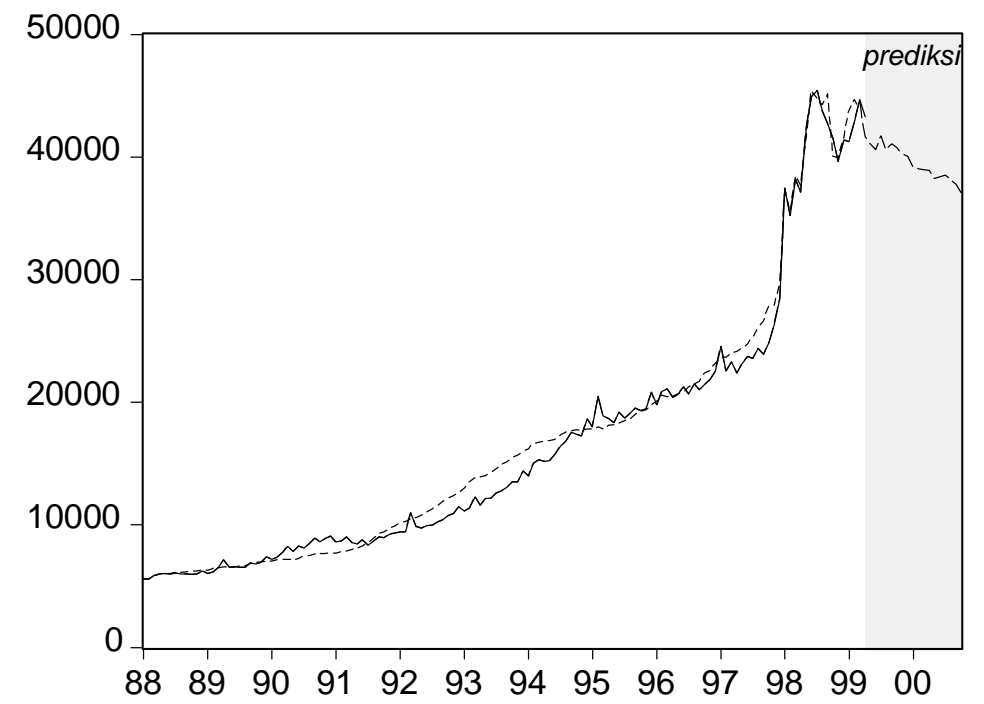

- CURRENCY --.--- CURRENCYFMOD ---- CURRENCYFORC 


\section{Kesimpulan}

Tulisan ini menemukan bukti bahwa permintaan uang riil di Indonesia tetap stabil sebelum dan selama krisis. A nal isis kointegrasi menggunakan teknik Johansen menunjukkan hubungan kointegrasi yang kuat antaracurrency riil dan PDB riil. Model dinamispermintaan uang riil menunjukkan konsistensi parameter yang ditaksir bahkan selama krisis terjadi. Dapat disimpulkan bahwa perubahan yang signifikan pada permintaan uang riil karena adanya krisis dapat dijelaskan dengan perubahan pada variabel-variabel yang secara historis memang mempengaruhi permintaan uang di Indonesia.

\section{D aftar Pustaka}

Charemza, Wojciech W., and Deadman, Derek F., N ew D irections in Econometric Practice, General to Specific M odelling, Cointegration and V ector A utoregression, Edward Elgar Publishing Limited, 1997.

Desk Penelitian dan Pengembangan Urusan Ekonomi dan Statistik, Stabilitas Permintaan Uang di Indonesia, Kertas Kerja Staf, Januari 1995.

Enders, Walter, A pplied Econometric TimeSeries, John Wiley \& Sons, Inc., 1995.

Kennedy, Peter, A Guide to Econometrics, the MIT Press, Cambridge, Massachusetts, 1996.

Khamis, May, and M.L. Alfredo, Can Currency beStable U nder a Financial Crisis ? The Case of M exico, IMF Working Paper, A pril 1999.

Mills, Terence C., Time Series Techniques for Economists, Cambridge University Press, 1990.

Rao, Bhaskara B., (edit.), Cointegration for the A pplied Economist, St. Martin's Press, Inc., 1994.

Solikin, The Stability of Income V elocity, D emand for M oney, and M oney M ultiplier in Indonesia, 1971 - 1996, Department of Economics, theUniversity of Michigan, Spring 1998. 


\section{Lampiran}

Uji kointegrasi pada Currency dan PDB Riil yang telah dilakukan seasonal adjustment dan uji unit root padaerror correctionnya (ECSA) :

Sample: 1988:01 1999:03

Included observations: 130

Test assumption: Linear deterministic trend in the data

Series: LOG(CURRSA/IHK) LOG(PDBRESA)

Lags interval: 1 to 4

$\begin{array}{ccccc}\text { Eigenvalue } & \begin{array}{c}\text { Likelihood } \\ \text { Ratio }\end{array} & \begin{array}{c}5 \text { Percent } \\ \text { Critical Value }\end{array} & \begin{array}{c}\text { 1 Percent } \\ \text { Critical Value }\end{array} & \begin{array}{c}\text { Hypothesized } \\ \text { No. of CE(s) }\end{array} \\ 0.119425 & 18.91704 & 15.41 & 20.04 & \text { None * }^{*} \\ 0.018169 & 2.383661 & 3.76 & 6.65 & \text { At most 1 }\end{array}$

${ }^{*}\left({ }^{* *}\right)$ denotes rejection of the hypothesis at $5 \%(1 \%)$ significance level

L.R. test indicates 1 cointegrating equation(s) at $5 \%$ significance level

Normalized Cointegrating Coefficients: 1 Cointegrating Equations(s)

LOG(CURRSA/IHK) LOG(PDBRESA) C

$1 \quad-1.1818804 \quad 12.38613$

$-0.07858$

Log Likelihood $\quad 776.6722$

\begin{tabular}{|c|c|c|c|c|}
\hline ADF Test Statistic & -2.184954 & $\begin{array}{ll}1 \% & \text { Critical } \\
5 \% & \text { Critical } \\
10 \% & \text { Critical }\end{array}$ & $\begin{array}{l}\text { Value* }^{*} \\
\text { Value } \\
\text { Value }\end{array}$ & $\begin{array}{l}-3.4804 \\
-2.8832 \\
-2.5782\end{array}$ \\
\hline $\begin{array}{l}\text { Augmented Dickey- } \\
\text { Dependent Variable } \\
\text { Method: Least Squa } \\
\text { Sample(adjusted): } 1 \\
\text { Included observatior }\end{array}$ & $\begin{array}{l}\text { Iler Test Equation } \\
\text { (ECSA) } \\
\text { s } \\
\text { 38:03 1999:03 } \\
133 \text { after adjusting }\end{array}$ & endpoints & unit root. & \\
\hline Variable & Coefficient & Std. Error & t-Statistic & Prob. \\
\hline $\operatorname{ECSA}(-1)$ & -0.017224 & 0.007883 & -2.184954 & 0.0307 \\
\hline $\mathrm{D}(\mathrm{ECSA}(-1))$ & -0.217819 & 0.084617 & -2.574173 & 0.0112 \\
\hline C & 0.188395 & 0.080747 & 2.333163 & 0.0212 \\
\hline R-squared & 0.075432 & Mean depenc & dent var & 0.010155 \\
\hline Adjusted R-squared & 0.061208 & S.D. depende & ent var & 0.047546 \\
\hline S.E. of regression & 0.046068 & Akaike info c & riterion & -3.295088 \\
\hline Sum squared resid & 0.275897 & Schwarz crite & erion & -3.229892 \\
\hline Log likelihood & 222.1234 & F-statistic & & 5.303137 \\
\hline Durbin-Watson stat & 1.929943 & Prob(F-statis & & 0.00611 \\
\hline
\end{tabular}


Penaksiran ECM dengan variabel yang telah dilakukan seasonal adjustment dan uji stabilitas pada d(log(currsa/ ink)) dengan Cusum of Square- Recursive :

Dependent Variable: D(LOG(CURRSA/IHK))

Method: Least Squares

Date: 03/10/00 Time: 07:31

Sample(adjusted): 1988:03 1999:03

\begin{tabular}{|llllc|}
\multicolumn{1}{c}{ Variable } & Coefficient & \multicolumn{1}{c}{ Std. Error } & t-Statistic & Prob. \\
C & & & \\
D(LOG(CURRSA(-1)/IHK(-1))) & -0.083625 & 0.064558 & 1.295336 & 0.1976 \\
D(DEP1(-1)) & -0.002257 & 0.070505 & -5.261116 & 0 \\
D(INFBUL(-1)) & -0.005875 & 0.002516 & -2.334945 & 0.0211 \\
D(ER) & $2.87 \mathrm{E}-05$ & $4.09 \mathrm{E}-06$ & 7.017407 & 0 \\
ECSA(-1) & -0.007619 & 0.006314 & -1.206755 & 0.2298 \\
& & & \\
R-squared & 0.378887 & Mean dependent var & 0.005045 \\
Adjusted R-squared & 0.354434 & S.D. dependent var & 0.045344 \\
S.E. of regression & 0.036433 & Akaike info criterion & -3.742647 \\
Sum squared resid & 0.168571 & Schwarz criterion & -3.612255 \\
Log likelihood & 254.886 & F-statistic & 15.49433 \\
Durbin-Watson stat & 1.992252 & Prob(F-statistic) & 0 \\
& &
\end{tabular}

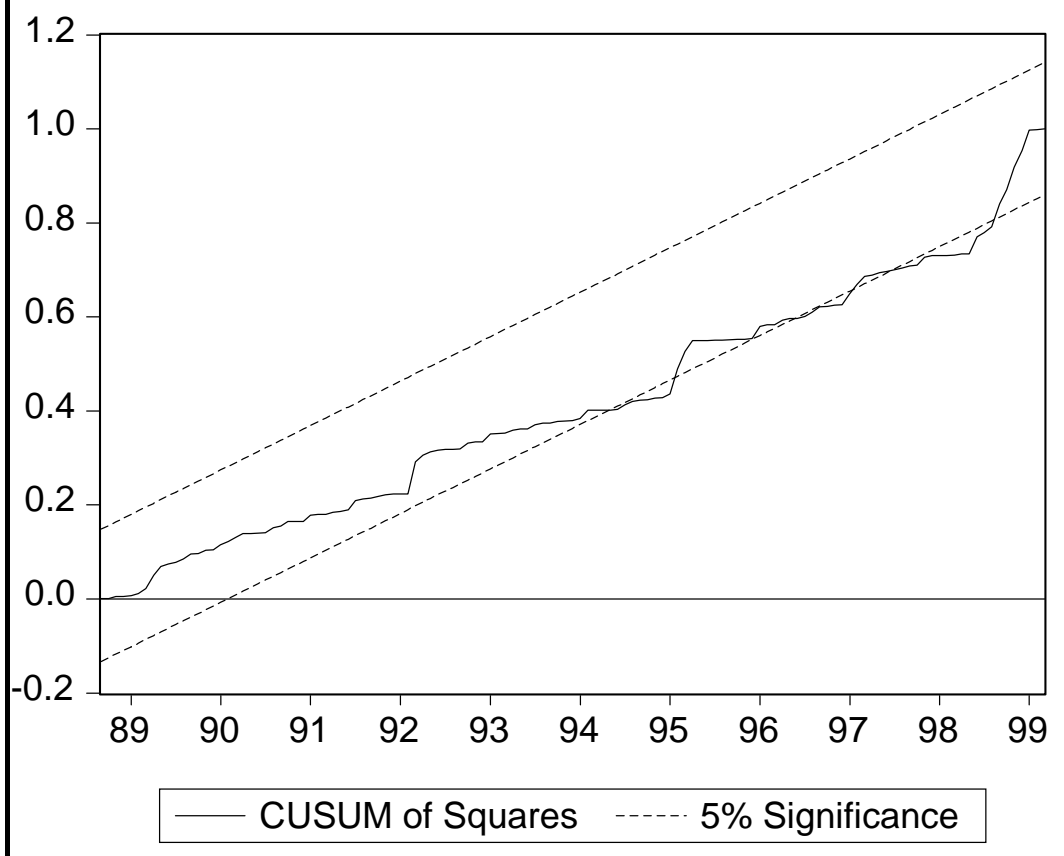


Uji normalitas residual ECM :

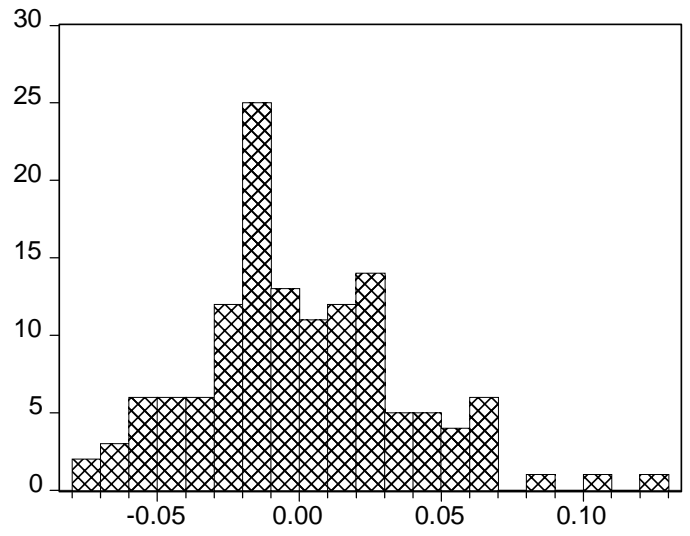

\begin{tabular}{|lr|}
\hline \multicolumn{2}{|l|}{ Series: Residuals } \\
Sample 1988:03 1999:03 \\
Observations 133 \\
Mean & $2.80 \mathrm{E}-17$ \\
Median & -0.004791 \\
Maximum & 0.123420 \\
Minimum & -0.077204 \\
Std. Dev. & 0.036406 \\
Skewness & 0.489809 \\
Kurtosis & 3.456423 \\
& \\
Jarque-Bera & 6.472510 \\
Probability & 0.039311 \\
\hline
\end{tabular}

Uji serial correlation pada residual dengan lag 11

\begin{tabular}{|c|c|c|c|c|}
\hline \multicolumn{5}{|c|}{ Breusch-Godfrey Serial Correlation LM Test: } \\
\hline F-statistic & 1.154511 & \multicolumn{2}{|l|}{ Probability } & 0.32651 \\
\hline Obs*R-squared & 13.12397 & \multirow{3}{*}{\multicolumn{2}{|c|}{ Probability }} & 0.2853 \\
\hline Test Equation: & & & & \\
\hline \multicolumn{3}{|c|}{$\begin{array}{l}\text { Dependent Variable: RESID } \\
\text { Method: Least Squares }\end{array}$} & & \\
\hline Variable & Coefficient & Std. Error & t-Statistic & Prob. \\
\hline C & $-7.45 \mathrm{E}-05$ & 0.00328 & -0.022703 & 0.9819 \\
\hline $\begin{array}{l}\text { D(LOG(CURRENCY(- } \\
1) / / H K(-1)))\end{array}$ & 0.021691 & 0.121884 & 0.177963 & 0.8591 \\
\hline $\mathrm{D}(\mathrm{DEP} 1(-1))$ & $9.21 \mathrm{E}-05$ & 0.001448 & 0.063611 & 0.9494 \\
\hline $\mathrm{D}(\mathrm{INFBUL}(-1))$ & $9.18 \mathrm{E}-05$ & 0.002724 & 0.033697 & 0.9732 \\
\hline $\mathrm{D}(\mathrm{ER})$ & $-2.01 E-07$ & $4.28 \mathrm{E}-06$ & -0.046991 & 0.9626 \\
\hline ECTRI(-1) & 0.014538 & 0.047643 & 0.30514 & 0.7608 \\
\hline RESID $(-1)$ & -0.058134 & 0.162603 & -0.357522 & 0.7214 \\
\hline RESID(-2) & -0.076197 & 0.115652 & -0.658848 & 0.5113 \\
\hline RESID(-3) & 0.061036 & 0.102429 & 0.59588 & 0.5524 \\
\hline RESID(-4) & -0.034675 & 0.100554 & -0.344841 & 0.7308 \\
\hline RESID $(-5)$ & 0.070423 & 0.099638 & 0.706784 & 0.4811 \\
\hline RESID(-6) & 0.05455 & 0.098181 & 0.555605 & 0.5796 \\
\hline RESID(-7) & 0.007476 & 0.099888 & 0.074847 & 0.9405 \\
\hline RESID(-8) & -0.140581 & 0.100249 & -1.402328 & 0.1635 \\
\hline RESID(-9) & 0.135473 & 0.101219 & 1.338422 & 0.1834 \\
\hline RESID(-10) & -0.198232 & 0.100267 & -1.977037 & 0.0504 \\
\hline RESID(-11) & -0.043232 & 0.100175 & -0.431568 & 0.6669 \\
\hline R-squared & 0.098676 & \multicolumn{2}{|c|}{ Mean dependent var } & $2.09 E-19$ \\
\hline Adjusted R-squared & -0.025644 & \multicolumn{2}{|c|}{ S.D. dependent var } & 0.036406 \\
\hline S.E. of regression & 0.036869 & \multicolumn{2}{|c|}{ Akaike info criterion } & -3.643992 \\
\hline Sum squared resid & 0.157684 & \multicolumn{2}{|c|}{ Schwarz criterion } & -3.274549 \\
\hline Loq likelihood & 259.3255 & \multicolumn{2}{|c|}{ F-statistic } & 0.793727 \\
\hline Durbin-Watson stat & 1.93214 & \multicolumn{2}{|c|}{ Prob(F-statistic) } & 0.68997 \\
\hline
\end{tabular}


Uji autoregressiveconditional heteroskedasticity pada residual :

\begin{tabular}{|c|c|c|c|c|}
\hline \multicolumn{5}{|l|}{ ARCH Test: } \\
\hline F-statistic & 1.283865 & \multicolumn{2}{|l|}{ Probability } & 0.259267 \\
\hline Obs*R-squared & 1.290868 & \multicolumn{2}{|l|}{ Probability } & 0.255888 \\
\hline \\
\hline \multicolumn{5}{|l|}{ Dependent Variable: } \\
\hline \multicolumn{5}{|c|}{ Method: Least Squares } \\
\hline \multicolumn{5}{|c|}{ Sample(adiusted): 1988:04 1999:03 } \\
\hline \multicolumn{5}{|c|}{ Included observations: 132 after adjusting endpoints } \\
\hline Variable & Coefficient & Std. Error & t-Statistic & Prob. \\
\hline C & 0.001174 & 0.000213 & 5.511281 & 0 \\
\hline $\operatorname{RESID} 2(-1)$ & 0.098962 & 0.087339 & 1.133078 & 0.2593 \\
\hline R-squared & 0.009779 & \multicolumn{2}{|c|}{ Mean depenident var } & 0.001303 \\
\hline Adjusted R-squared & 0.002162 & \multicolumn{2}{|c|}{ S.D. dependinnt var } & 0.002072 \\
\hline S.E. of regression & 0.00207 & \multicolumn{2}{|c|}{ Akaike info criterion } & -9.507793 \\
\hline Sum squared resid & 0.000557 & \multicolumn{2}{|c|}{ Schwarz criterion } & -9.464115 \\
\hline Log likelihood & 629.5144 & \multicolumn{2}{|c|}{ F-statistic } & 1.283865 \\
\hline Durbin-Watson stat & 2.027527 & \multicolumn{2}{|c|}{ Prob(F-statistic) } & 0.259267 \\
\hline
\end{tabular}

Uji heteroskedasticity pada residual :

\begin{tabular}{|c|c|c|c|c|}
\hline \multicolumn{5}{|l|}{ White Heteroskedasticity Test: } \\
\hline F-statistic & 1.129633 & \multicolumn{2}{|l|}{ Probability } & 0.345774 \\
\hline Obs*R-squared & 11.27121 & \multicolumn{2}{|l|}{ Probability } & 0.336782 \\
\hline \multicolumn{5}{|l|}{ Dependent Variable: RESID^2 } \\
\hline \multicolumn{5}{|l|}{ Date: 03/10/00 Time: 08:21 } \\
\hline \multicolumn{5}{|l|}{ Sample: 1988:03 1999:03 } \\
\hline Variable & Coefficient & Std. Error & t-Statistic & Prob. \\
\hline C & 0.001299 & 0.000228 & 5.689565 & 0 \\
\hline D(LOG(CURRENCY(-1)/IHK(- & -0.001245 & 0.003757 & -0.331404 & 0.7409 \\
\hline (D)(LOG(CURRENCY(-1)/lHK( & 0.100083 & 0.051339 & 1.949468 & 0.0535 \\
\hline $\mathrm{D}(\mathrm{DEP} 1(-1))$ & $-7.90 \mathrm{E}-05$ & 8.62E-05 & -0.915819 & 0.3616 \\
\hline$(\mathrm{D}(\mathrm{DEP} 1(-1)))^{\wedge} 2$ & 4.57E-06 & 9.47E-06 & 0.482887 & 0.63 \\
\hline $\mathrm{D}($ INFBUL $(-1))$ & -0.000333 & 0.000175 & -1.904646 & 0.0592 \\
\hline$(\mathrm{D}(\mathrm{INFBUL}(-1)))^{\wedge} 2$ & $-4.42 E-05$ & 4.93E-05 & -0.896102 & 0.372 \\
\hline $\mathrm{D}(\mathrm{ER})$ & $-3.68 E-07$ & 3.60E-07 & -1.021943 & 0.3088 \\
\hline$(\mathrm{D}(\mathrm{ER}))^{\wedge} 2$ & $1.37 \mathrm{E}-10$ & $8.49 E-11$ & 1.61681 & 0.1085 \\
\hline ECTRI $(-1)$ & 0.002317 & 0.002566 & 0.902745 & 0.3684 \\
\hline $\operatorname{ECTRI}(-1)^{\wedge} 2$ & -0.024625 & 0.013285 & -1.853641 & 0.0662 \\
\hline R-squared & 0.084746 & Mean dep & nt var & 0.001315 \\
\hline Adjusted R-squared & 0.009725 & S.D. depe & t var & 0.002069 \\
\hline S.E. of regression & 0.002059 & Akaike inf & erion & -9.453791 \\
\hline Sum squared resid & 0.000517 & Schwarz c & & -9.21474 \\
\hline Log likelihood & 639.6771 & F-statistic & & 1.129633 \\
\hline Durbin-Watson stat & 1.983326 & Prob(F-sta & & 0.345774 \\
\hline
\end{tabular}


Uji stabilitas parameter ECM dengan Chow Breakpoint:

\begin{tabular}{|lccc|}
\hline Chow Breakpoint Test: 1988:10 & & & \\
F-statistic & 0.672768 & Probability & 0.671827 \\
Loo likelihood ratio & 4.364527 & Probability & 0.627473 \\
\hline Chow Breakpoint Test: 1991:02 & & & \\
& 1.087875 & Probability & 0.373541 \\
F-statistic & 6.987755 & Probability & 0.321981 \\
Log likelihood ratio & & & 0.654889 \\
\hline Chow Breakpoint Test: 1997:08 & & Probability & 0.609342 \\
\hline F-statistic & 0.694002 & Probability \\
Log likelihood ratio & 4.499976 & &
\end{tabular}

Uji stabilitas parameter ECM dengan Chow Forecast:

\begin{tabular}{|c|c|c|c|c|}
\hline \multicolumn{5}{|c|}{ Chow Forecast Test: Forecast from 1988:10 to $1999: 03$} \\
\hline F-statistic & 80.98083 & Probability & & 0.088305 \\
\hline Log likelihood ratio & 1227.669 & Probability & & 0 \\
\hline Dependent Variable: D & RRENCY/IHr & & & \\
\hline Method: Least Squares & & & & \\
\hline $\begin{array}{l}\text { Sample: 1988:03 } 1988 \\
\text { Included observations: }\end{array}$ & & & & \\
\hline Variable & Coffiginnt & Ctd Error & tototicti & Drob \\
\hline raniono & -0.018249 & 0.009952 & -1.833669 & 0.3178 \\
\hline D(LOG(CURRENCY(- & -0.78692 & 0.154559 & -5.091399 & 0.1235 \\
\hline 1)/IHK(-1))) & & & & \\
\hline$D(D E P 1(-1))$ & 0.057954 & 0.017365 & 3.337391 & 0.1853 \\
\hline $\mathrm{D}(\mathrm{INFBUL}(-1))$ & -0.021957 & 0.003113 & -7.053401 & 0.0897 \\
\hline $\mathrm{D}(\mathrm{ER})$ & -0.001721 & 0.000765 & -2.248951 & 0.2664 \\
\hline ECTRI(-1) & 0.461653 & 0.084155 & 5.485753 & 0.1148 \\
\hline R-squared & 0.993721 & Mean depend & nt var & 0.005604 \\
\hline Adjusted R-squared & 0.962325 & S.D. depende & t var & 0.021332 \\
\hline S.E. of regression & 0.004141 & Akaike info $\mathrm{cr}$ & erion & -8.367608 \\
\hline Sum squared resid & $1.71 \mathrm{E}-05$ & Schwarz crite & & -8.413971 \\
\hline Log likelihood & 35.28663 & F-statistic & & 31.65095 \\
\hline Durbin-Watson stat & 3.515371 & Prob(F-statist & & 0.134103 \\
\hline
\end{tabular}


Uji stabilitas parameter ECM dengan Chow Forecast:

\begin{tabular}{|c|c|c|c|c|}
\hline \multicolumn{5}{|c|}{ Chow Forecast Test: Forecast from 1997:08 to $1999: 03$} \\
\hline F-statistic & 1.189916 & \multicolumn{2}{|l|}{ Probability } & 0.2773 \\
\hline Log likelihood ratio & 26.71009 & Probability & & 0.143619 \\
\hline \multicolumn{5}{|c|}{$\begin{array}{l}\text { Dependent Variable: D(LOG(C:URRENCY//HK)) } \\
\text { Method: Least Squares }\end{array}$} \\
\hline \multirow{2}{*}{\multicolumn{5}{|c|}{ Sample: 1988:03 1997:07 }} \\
\hline & & & & \\
\hline Variable & Coefficient & Std. Error & $\mathrm{t}$-Statistic & Prob. \\
\hline C & 0.007276 & 0.004275 & 1.702119 & 0.0916 \\
\hline D(LOG(CURRENCY(- & -0.413885 & 0.088069 & -4.699569 & 0 \\
\hline $\begin{array}{l}\text { D } \\
D(D E P 1(-1))\end{array}$ & -0.00223 & 0.006573 & -0.339218 & 0.7351 \\
\hline $\mathrm{D}(\mathrm{INFBUL}(-1))$ & -0.010821 & 0.004456 & -2.428303 & 0.0168 \\
\hline $\mathrm{D}(\mathrm{ER})$ & $-9.66 \mathrm{E}-05$ & 0.000238 & -0.405864 & 0.6857 \\
\hline ECTRI (-1) & -0.130033 & 0.064877 & -2.004313 & 0.0476 \\
\hline R-squared & 0.286565 & Mean depe & nt var & 0.00648 \\
\hline Adjusted R-squared & 0.253227 & S.D. deper & t var & 0.042321 \\
\hline S.E. of regression & 0.036572 & Akaike info & erion & -3.727412 \\
\hline Sum squared resid & 0.143117 & Schwarz cl & & -3.582595 \\
\hline Log likelihood & 216.5988 & F-statistic & & 8.595719 \\
\hline Durbin-Watson stat & 1.990346 & Prob(F-sta & & 0.000001 \\
\hline
\end{tabular}

Uji stabilitas parameter dengan Ramsey Reset:

\begin{tabular}{|c|c|c|c|c|}
\hline \\
\hline \multicolumn{5}{|l|}{$\begin{array}{l}\text { Ramsey RESET Test: } \\
\text { F-statistic }\end{array}$} \\
\hline Log likelihood ratio & 0.95432 & \multicolumn{2}{|l|}{ Probability } & 0.328622 \\
\hline \multirow{2}{*}{\multicolumn{5}{|c|}{ Dependent Variable: D(LOG(CURRENCY/IHK)) }} \\
\hline \multicolumn{2}{|c|}{ Method: Least Squares } & & & \\
\hline \multirow{2}{*}{\multicolumn{5}{|c|}{$\begin{array}{l}\text { Sample: 1988:03 1999:03 } \\
\text { Included observations: } 133\end{array}$}} \\
\hline & & & & \\
\hline Variable & Coefficient & Std. Error & t-Statistic & Prob. \\
\hline C & 0.005195 & 0.003407 & 1.524675 & 0.1298 \\
\hline $\begin{array}{l}\text { D(LOG(CURRENCY(- } \\
1) / / H K(-1)))\end{array}$ & -0.38715 & 0.06941 & -5.577691 & 0 \\
\hline $\mathrm{D}(\mathrm{DEP} 1(-1))$ & -0.002047 & 0.001405 & -1.456833 & 0.1477 \\
\hline D(INFBUL(-1)) & -0.005397 & 0.002742 & -1.968211 & 0.0512 \\
\hline $\mathrm{D}(\mathrm{ER})$ & 2.97E-05 & 4.15E-06 & 7.160131 & 0 \\
\hline ECTRI(-1) & -0.166178 & 0.038279 & -4.341282 & 0 \\
\hline FITTED^2 & 0.964392 & 1.012436 & 0.952546 & 0.3426 \\
\hline R-squared & 0.464644 & \multicolumn{2}{|c|}{ Mean dependent var } & 0.005255 \\
\hline Adjusted R-squared & 0.439151 & \multicolumn{2}{|c|}{ S.D. dependent var } & 0.049578 \\
\hline S.E. of regression & 0.037129 & \multicolumn{2}{|c|}{ Akaike info criterion } & -3.697653 \\
\hline Sum squared resid & 0.173697 & \multicolumn{2}{|c|}{ Schwarz criterion } & -3.545529 \\
\hline Log likelihood & 252.8939 & \multicolumn{2}{|c|}{ F-statistic } & 18.22626 \\
\hline Durbin-Watson stat & 2.031406 & \multicolumn{2}{|c|}{ Prob(F-statistic) } & 0 \\
\hline
\end{tabular}

